\title{
NONGAME FISH SPECIES DISTRIBUTION AND HABITAT ASSOCIATIONS IN THE SNAKE RIVER BASIN OF SOUTHERN IDAHO
}

\author{
Kevin A. Meyer ${ }^{1,3}$, James A. Lamansky Jr. ${ }^{1}$, Daniel J. Schill ${ }^{1}$, and Donald W. Zaroban ${ }^{2}$
}

\begin{abstract}
Aвstract.-The distribution and abundance of game fish populations are commonly monitored closely, whereas sampling of nongame species is often neglected. We used a broad-scale salmonid sampling project both to simultaneously assess the distribution and relative abundance of nongame fish species in small streams (i.e., $\leq 15 \mathrm{~m}$ wetted width) in the Snake River basin of southern Idaho and to relate the distribution and abundance of nongame species to abiotic and biotic stream conditions in the study area. Of the 1738 reaches surveyed, $34 \%$ were dry or contained too little water to support fish, and an additional $21 \%$ had flowing water but were still absent of fish. At least one species of nongame fish was captured at $30 \%$ of the reaches surveyed, and all 18 native nongame fish species believed present in study area streams were captured. The most widely distributed species was speckled dace Rhinichthys osculus (present in $21 \%$ of surveyed reaches, excluding dry and nearly dry reaches), followed by bridgelip sucker Catostomus columbiamus (19\%), Paiute sculpin Cottus beldingi (15\%), and redside shiner Richardsonius balteatus (13\%). The species least often present $(\leq 1 \%)$ were leopard dace Rhinichthys falcatus and peamouth Mylocheilus caurinus. Common carp Cyprinus carpio (captured at 3 locations) and oriental weatherfish Misgurnus anguillicaudatus (2 locations) were the only nonnative nongame species encountered. Catostomids and cyprinids generally formed a composite fish assemblage that was associated with higher stream order (i.e., farther from headwaters), lower elevation, and lower-gradient reaches where streams were wider and deeper. Stream order was the strongest loading factor for canonical correlations constructed for study reaches both above and below Shoshone Falls, suggesting that the increased abundance of catostomids and cyprinids generally occurred on a longitudinal downstream gradient. Biologists sampling game fish populations in streams should also record data on nongame species to more closely monitor their status through time.
\end{abstract}

Resumen.-La distribución y abundancia de las poblaciones de peces de valor deportivo (game fish) comúnmente se monitorean cercanamente, mientras que el muestreo de especies de peces que no son de valor por lo general suele descuidarse. Utilizamos un proyecto de muestreos de salmónidos a gran escala para evaluar de manera simultánea la distribución y la abundancia relativa de especies de peces que no son de valor en arroyos pequeños (i.e., $\leq 15 \mathrm{~m}$ de ancho), en la cuenca del Río Snake en el sur de Idaho y para relacionar su distribución y abundancia con las condiciones bióticas y abióticas del arroyo en el área de estudio. De los 1738 tramos revisados, el 34\% estaban secos o contenían muy poca agua para mantener a los peces, y un $21 \%$ adicional tuvo caudal de agua pero tampoco se encontraron peces. Se capturó al menos una especie de pez que no es de valor en el $30 \%$ de los tramos revisados, y se capturaron las 18 especies nativas de peces que no son de valor y que se estimaban presentes en los arroyos del área de estudio. Las especies más ampliamente distribuidas fueron Rhinichthys osculus (presente en $21 \%$ de los tramos revisados, sin incluir los tramos secos y casi secos), seguido por Catostomus columbianus (19\%), Cottus beldingi (15\%) y Richardsonius balteatus (13\%), mientras que las especies menos presentes $(\leq 1 \%)$ fueron Rhinichthys falcatus y Mylocheilus caurinus. La carpa común Cyprinus carpio (capturada en tres sitios) y Misgurnus anguillicaudatus (dos sitios) fueron las únicas especies encontradas que son no nativas y que no poseen valor. Los catostómidos y ciprínidos generalmente formaron un ensamble compuesto de peces que estuvo asociado con arroyos de orden superior (es decir, más lejos de las partes altas del río), menor elevación y tramos de gradiente más bajo donde los arroyos fueron más amplios y profundos. El orden del arroyo fue el factor con carga más alta en las correlaciones canónicas construidas para los tramos revisados tanto por encima y por debajo de las Cataratas Shoshone, lo que sugiere que la creciente abundancia de catostómidos y ciprínidos generalmente ocurrió en un gradiente longitudinal aguas abajo. Los biólogos que toman muestras de las poblaciones de peces de valor deportivo en arroyos también deben registrar datos de las especies que no poseen valor, para supervisar su estado con mayor detalle a través del tiempo.

The Snake River basin above Hells Canyon Dam comprises approximately $58 \%$ of the land surface area of Idaho (Fig. 1). Since settlement in the 1800s by humans of European descent, aquatic resources in the Snake River basin, as in the rest of western North America, have undergone extensive alterations due to hydropower, agriculture, grazing, mining, logging, and other extraction-based land uses. Despite these impacts, the only fish species extirpated

\footnotetext{
${ }^{1}$ Idaho Department of Fish and Game, 1414 East Locust Lane, Nampa, ID 83686.

${ }^{2}$ Idaho Department of Environmental Quality, 1410 N. Hilton Street, Boise, ID 83706

${ }^{3}$ E-mail: kevin.meyer@idfg.idaho.gov
} 


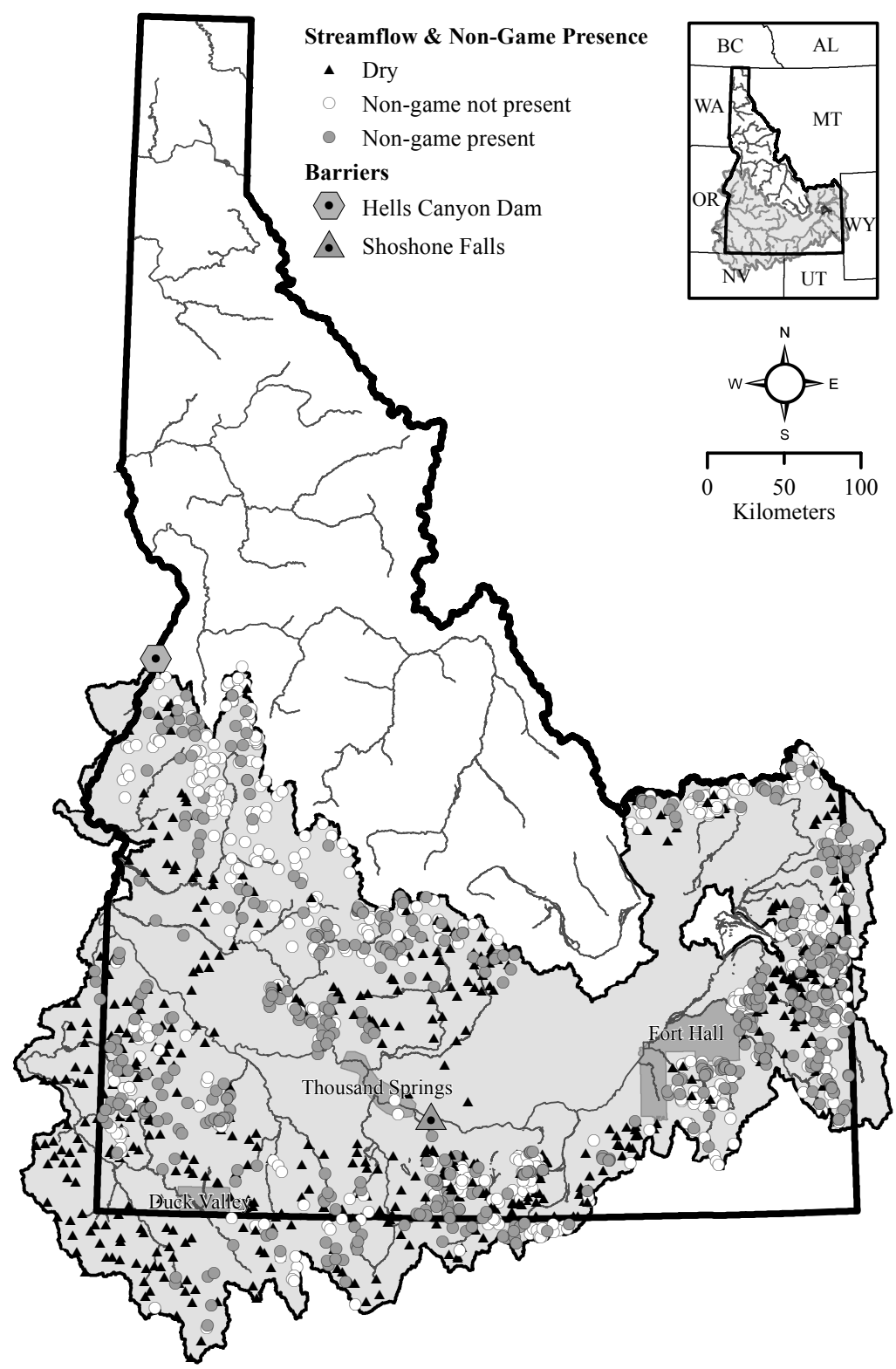

Fig. 1. Locations where the distribution and relative abundance of nongame fish species were examined in the Snake River basin of southern Idaho.

from the Snake River basin in southern Idaho are anadromous species (salmon and lamprey) whose passage has been blocked by dams lacking fish ladders. Due to their sportfishing and aesthetic value, native game fish populations in the basin have been closely monitored (e.g., Meyer et al. 2006, 2009, High et al. 2008, Schill 2009), in part so that management practices such as harvest regulations can be adjusted if fish population metrics indicate changes are needed. In general, the economic or intrinsic values of native nongame fish species are rarely altered by the recreational community, thus management regulations for native nongame species have rarely been necessary, and population monitoring has therefore rarely been conducted. This lack of information is an impediment to understanding the conservation 
status of many native nongame fish species in Idaho (IDFG 2007).

The Snake River basin above Hells Canyon Dam historically supported 26 native fish species (Simpson and Wallace 1982), 20 of which are considered nongame species. Fish distribution patterns in the Snake River basin have been influenced by numerous climatic and geologic events. Smith (1978) argued that the predominant factors affecting fish fauna patterns in the Intermountain Region of the western United States are the degree of isolation between basins and the late Cenozoic history of fluctuating wet and dry periods, which also included glaciation. In addition, late Pleistocene volcanic activity in the region repeatedly altered drainage patterns and may have exterminated some or all fishes from the upper Snake River basin (Hubbs and Miller 1948, Johnson 2002). Shoshone Falls, a 65-m high waterfall on the Snake River at river kilometer 992 (Fig. 1), precluded the invasion of many Columbia River fish species (such as redband trout Oncorhynchus mykiss gairdneri and northern pikeminnow Ptychocheilus oregonensis) into the upper drainages of the Snake River basin. Taken collectively, these processes form a multifaceted history of hydrologic isolation, diversion, and reconnection and have resulted in a complex pattern of fish distribution in the Snake River basin.

Overlaying this complex hydrologic history is the fact that fish distribution patterns are also affected by combinations of local biotic and abiotic factors, and associated regional factors, that determine how suitable stream reaches are for particular species (Angermeier and Winston 1998, Hughes et al. 2006). For example, stream size, elevation, channel gradient, water temperature, and substrate composition have commonly been shown to influence the distribution and relative abundance of nongame fish species across North America (e.g., Grossman et al. 1998, Quist et al. 2004c, 2004a, Rashleigh et al. 2005, Torgersen et al. 2006). Understanding fish distribution patterns across the landscape and mechanisms that influence fish assemblages can contribute important knowledge for management and conservation purposes. For instance, a common purpose of developing relationships between fish assemblages and both abiotic and biotic stream conditions is to develop indices of biological integrity to assess environmental quality in flowing waters (e.g., Mebane et al. 2003) or to facilitate preservation and rehabilitation of riverine ecosystems (e.g., Scott and Hall 1997, Hughes et al. 1998).

Information regarding species assemblages and stream habitat conditions across the landscape is especially lacking in the Intermountain Region of the western United States (Quist et al. 2004c), where fish assemblages are relatively depauperate compared to streams in eastern North America (Lee et al. 1980). Establishing relationships between stream-dwelling fish and their environment is often problematic because these types of studies are often focused at small scales (Fausch et al. 1988). Although they may adequately describe fish distribution or abundance patterns within a particular study area, small-scale studies may have limited ability to explain patterns across the landscape if inadequate sample sizes failed to fully characterize fish-habitat associations, or if the limited study area was not representative of other areas of a species' range.

The primary objective of this paper was to fill the aforementioned data gap regarding the distribution and abundance of nongame fish (native and nonnative) species in the Snake River basin above Hells Canyon Dam. To accomplish this objective, we used field crews deployed to collect data on stream-dwelling salmonids across the landscape to simultaneously gather quantitative information on nongame species occupying lotic environments in the study area. Because little work has been done to describe fish-habitat associations for nongame fish species in the Snake River basin in southern Idaho, a second objective was to assess which abiotic and biotic stream conditions were associated with the distribution and relative abundance of these species. Our large, spatially balanced sample size (over 1700 stream surveys) over a broad geographic scale helped circumvent the aforementioned limitations of studies of fish-habitat associations.

\section{Methods}

\section{Study Area}

The Snake River in Idaho flows approximately $1000 \mathrm{~km}$ from east to west across southern Idaho, then flows north to the confluence with the Columbia River. The study area included most of the Snake River basin (approximately 84,000 $\mathrm{km}^{2}$ ) above Hells Canyon Dam 
(Fig. 1). We excluded the Malheur River, Powder River, Burnt River, and Pine Creek drainages because they reside entirely in Oregon, and we also excluded the Snake River drainage in Wyoming (upstream of Palisades Reservoir), except for those tributaries that were contained at least in part within Idaho. Similarly, Nevada, Utah, and Oregon basins were included if they were contained at least partly within Idaho. Within Idaho, we did not sample the Lost River drainages (Birch Creek, Little Lost River, Big Lost River) or streams located within the boundaries of the Duck Valley and Fort Hall Indian reservations (Fig. 1). We also excluded the copious springs directly adjacent to the Snake River in south central Idaho, known as the Thousand Springs, for 2 reasons. First, these springs represent very unique habitat in the study area, and many of these springs are actually more like lentic habitats than streams. Also, most of these springs are immediately adjacent or closely proximal to the Snake River, and species presence is often more strongly influenced by the fish assemblage of the Snake River than the habitat characteristics of the spring.

Within this study area, native nongame fish species include 5 catostomids (bluehead sucker Catostomus discobolus, bridgelip sucker Catostomus columbianus, largescale sucker Catostomus macrocheilus, mountain sucker Catostomus platyrhynchus, and Utah sucker Catostomus ardens); 9 cyprinids (chiselmouth Acrocheilus alutaceus, leopard dace Rhinichthys falcatus, longnose dace Rhinichthys cataractae, northern leatherside chub Lepidomeda copei, northern pikeminnow, peamouth Mylocheilus caurinus, redside shiner Richardsonius balteatus, speckled dace Rhinichthys osculus, and Utah chub Gila atraria); and 4 cottids (mottled sculpin Cottus bairdi, Paiute sculpin Cottus beldingi, shorthead sculpin Cottus confusus, and Wood River sculpin Cottus leiopomus). Shoshone sculpin Cottus greenei is also native to the study area but only occurs in the Thousands Springs area of south central Idaho, not in any particular river drainages. Pacific lamprey Entosphenus tridentata were native below Shoshone Falls but were extirpated from the study area long ago by a series of ladderless dams built on the Snake River and many tributaries.

\section{Fish Sampling}

Between 1999 and 2005, we surveyed stream reaches throughout the Snake River basin in southern Idaho from mid-June to mid-October, after high spring flows had receded. Study reaches were distributed randomly across a 1:100,000-scale stream network in first- through sixth-order streams (Strahler 1964) based proportionally on the length of stream within each stream-order stratum. However, streams that were greater than $15 \mathrm{~m}$ wide (mean wetted width) or $1 \mathrm{~m}$ deep (average depth) were excluded so that backpack electrofishing could be used to collect fish. These exclusions eliminated $3 \%$ of the randomly drawn samples but were necessary because the wide stream width and deeper water reduced our ability to efficiently collect small nongame fish, making fish capture data unreliable at these locations.

We attempted to sample 100 linear meters of stream at each survey location, but due to stream conditions, riparian vegetation, and our ability to set lower and upper blocknets, study reaches ranged from 25 to $337 \mathrm{~m}$ in length $(\bar{x}=$ $98 \mathrm{~m}$ ). Blocknets (7-mm mesh size) were installed to prevent fish movement out of the reach during sampling.

We collected fish with Smith-Root Model 15D backpack electrofishers at settings of 1-3 ms pulses, $30-60 \mathrm{~Hz}$, and 200-700 V. One to 4 electrofishing passes were conducted using 1-3 electrofishers (depending on stream size, water volume, and stream gradient) to deplete salmonids for population estimation. At the same time, nongame fish species were netted and identified to species, but they were not depleted. Rather, while electrofishing, we approximated an index of abundance by visually estimating the numerical abundance of each nongame fish species. This approximation often was accomplished by netting each nongame fish observed, but, at reaches where some species were highly abundant, estimates of abundance for some species were approximated by counting fish of that species as they were stunned, without netting every fish. After all the passes were completed, we used a scale similar to Grossman et al. (1998) to categorize each species (at a scale of 100 linear meters of stream, which was about our average reach length) as absent (0), sparse (1-10), common (10-50), or abundant (50-100 or more).

We vouchered a total of 981 nongame fish specimens from 107 study reaches throughout the study area to corroborate our identifications of fish species. Vouchered specimens were preserved in $10 \%$ formalin and were later 
identified by zoological staff at the Orma J. Smith Museum of Natural History. Field crews identified species correctly $86 \%$ of the time, and most errors involved incorrectly identifying Paiute or shorthead sculpin as mottled sculpin. Because the nonsculpin error rate was low $(6 \%)$, we assumed our occupancy (i.e., present or absent) and relative abundance data were correct for all species except sculpin. We corrected errors for these 3 sculpin species at reaches where vouchers were collected. In addition, we collected an additional 409 sculpin specimens from 41 additional study reaches to verify sculpin species distribution in the study area. Finally, the database of vouchered sculpin specimens at the Orma J. Smith Museum $(n=1361$ records for the study area) was used to corroborate any further questionable identifications.

\section{Abiotic and Biotic Stream Conditions}

We assessed several abiotic and biotic stream conditions that we felt could potentially influence nongame fish occurrence or abundance at a study reach. Elevation $(\mathrm{m})$ was determined from USGS 1:24,000-scale maps at the downstream end of each reach, based on coordinates obtained from GPS units. Stream gradient $(\%)$ was estimated using All Topo Maps Version 2.1 for Windows software (iGage Mapping Corporation, Salt Lake City, UT) by tracing (at 1:24,000 scale) the length of stream between 2 or 3 contour lines incorporating the reach (approximately $1 \mathrm{~km}$ ) and dividing the stream length by the elevation change between the contour lines. Specific conductivity $(\mu S$. $\mathrm{cm}^{-1}$ ) was measured with a calibrated, handheld conductivity meter accurate to $\pm 2 \%$.

Ten equally spaced transects were established throughout each sample reach and were used for the remaining measurements. Average stream wetted width $(\mathrm{m})$ was calculated from the 10 transect readings. Across transects, mean water depth was estimated by using a stadia rod to measure depth at $1 / 4,1 / 2$, and $3 / 4$ distance across the channel, and the sum of the measurements was divided by 4 to account for zero depths at the stream margins for trapezoidal-shaped channels (Arend 1999). From these measurements, we calculated the width: depth ratio. Substrate composition was visually estimated as the percentage of stream bottom within $1 \mathrm{~m}$ of each transect that was comprised of silt $(<0.06 \mathrm{~mm}$, diameter of $\mathrm{b}$ axis), sand (0.06-1.99 mm), gravel $(2-63 \mathrm{~mm})$, cobble (64-249 mm), boulder (250-3999 mm), or bedrock $(>4000 \mathrm{~mm})$. To reduce the number of independent variables considered in our analyses, however, silt, sand, and bedrock were discarded because they were heavily skewed toward zeros or low values. Cobble and boulder substrate likely affect many fishes in a similar manner (Allan 1995) and were therefore combined into one percentage value. Percent unstable banks and stream shading were also visually estimated within $1 \mathrm{~m}$ of each transect. All ocular estimates were averaged across all transects, yielding an overall mean for each study reach.

One additional stream condition that was considered to potentially affect occupancy and relative abundance of nongame fish species was trout density in the stream reach. In our study area, we encountered rainbow trout $\mathrm{On}$ corhynchus mykiss, cutthroat trout Oncorhynchus clarkii, brook trout Salvelinus fontinalis, bull trout Salvelinus confluentus, and brown trout Salmo trutta, all of which prey on nongame fish species in some stream settings (Scott and Crossman 1973, Wydoski and Whitney 2003). Consequently, we pooled the abundance of all trout as an additional stream condition that may have influenced the distribution and abundance of nongame fish species in our study area.

\section{Data Analyses}

For the 9 species that occupied at least 30 study reaches, we used logistic regression analysis to assess the relationship between the abiotic and biotic stream conditions and the relative abundance of nongame fish species. A benefit of using logistic regression is that the technique does not require that variables be normally distributed or of equal variance (Tabachnick and Fidell 1989). We assessed multicollinearity in the independent variables by calculating variance inflation factors (VIFs), all of which were $<5.0$, indicating that multicollinearity was low in our data set (Menard 1995). Moreover, correlation coefficients $(r)$ between independent variables were $>0.40$ for only 2 comparisons (stream width vs. stream depth, $r=0.53$; stream width vs. width: depth ratio, $r=0.58$ ).

Separate logistic regression models were constructed for each species. For the response variable, we assigned index values to the relative abundance data $(0=$ absent, $1=$ sparse, $2=$ 
TABle 1. Descriptive statistics for various abiotic and biotic stream parameters at study reaches $(n=1152)$ in the Snake River basin of southern Idaho. Dry reaches $(n$ $=586$ ) were not included in these calculations.

\begin{tabular}{lcccc}
\hline $\begin{array}{l}\text { Stream habitat } \\
\text { parameter }\end{array}$ & Mean & SD & Min. & Max. \\
\hline Stream order & 2.2 & 1.0 & 1.0 & 6.0 \\
$\begin{array}{l}\text { Elevation }(\mathrm{m}) \\
\text { Stream gradient }(\%)\end{array}$ & 1747 & 328 & 696 & 2964 \\
$\begin{array}{l}\text { Specific conductivity } \\
\quad\left(\mu \mathrm{S} \cdot \mathrm{cm}^{-1}\right)\end{array}$ & 200 & 170 & 0.1 & 32.5 \\
$\begin{array}{l}\text { Stream width }(\mathrm{m}) \\
\text { Average depth }(\mathrm{m})\end{array}$ & 3.3 & 2.4 & 0.5 & 14.2 \\
Width:depth ratio & 26.9 & 13.1 & 1.7 & 127.0 \\
$\begin{array}{l}\text { Gravel substrate }(\%) \\
\text { Cobble-boulder }\end{array}$ & 29 & 11 & 0 & 80 \\
$\quad$ substrate $(\%)$ & 34 & 19 & 0 & 100 \\
$\begin{array}{l}\text { Stream shading }(\%) \\
\text { Unstable banks }(\%)\end{array}$ & 21 & 21 & 0 & 88 \\
Trout density & 8 & 15 & 0 & 88 \\
$\quad\left(\right.$ number $\left.\cdot \mathrm{m}^{-2}\right)$ & 0.16 & 0.32 & 0.00 & 3.91 \\
\hline
\end{tabular}

common, $3=$ abundant) and to the occupancy data $(0=$ absent, $1=$ present $)$, and we produced models for each, but because the results were nearly identical, we present only the occupancy models. Stepwise methods were used for including independent variables in the models, and adjusted $R^{2}$ for discrete models (hereafter termed $\tilde{R}^{2}$; Nagelkerke 1991) was used to assess the amount of variation explained by the models. Only first-order interactions were tested for significance, and they were rarely significant for the best models. To reduce typeI error rate inflation caused by the inclusion of multiple independent variables in multiple individual logistic regressions, we set $\alpha=0.01$ for stepwise inclusion. For each species, we included in our analyses only those study reaches within the native distribution for that particular species. We used the Hosmer and Lemeshow goodness-of-fit test to ensure the data adequately fit logistic regression models for each species, and this test failed to reject the fit of any of our final models. We used the estimate of the area under the receiver operating characteristic (ROC) curve to assess the predictive ability of the final models (Hanley and McNeil 1982). We did not include any quadratic terms because species occupancy data was not parabolic in shape when plotted against any abiotic or biotic stream conditions.

In addition to the above logistic regression analyses, we used canonical correlation analyses to relate the suite of abiotic and biotic stream conditions to the relative abundance of all nongame fish species simultaneously. Canonical correlation analysis is a multivariate statistical model that facilitates the study of relationships among a set of multiple dependent variables and multiple independent variables. This analysis reduces the concern of committing type I errors due to multiple statistical tests on the same independent variables (thus we relaxed $\alpha$ to 0.05$)$. Canonical correlation analysis is therefore an ideal analytical tool for elucidating relationships between biological assemblages of species and their environment (ter Braak and Verdonschot 1995).

Since sampling efficiency of using backpack electrofishers is generally low for most streamdwelling nongame fish species (Reynolds et al. 2003, Burns 2007, Reid et al. 2008), we assumed that, when indexing fish abundance, we observed or captured only a fraction of the total number of fish of each species in any given study reach. Accordingly, we rounded each abundance index value to the upper end of the category (e.g., all "sparse" delineations were given an abundance value of 10). These data were square-root transformed prior to model construction to increase linearity (i.e., moderate skewness) in the fish-habitat relationships. As recommended by Hair et al. (1998), we interpreted relationships between fish and habitat parameters by using canonical crossloadings, and we used loading values of 0.3 and greater to indicate which parameters were robust contributors for each interpretable canonical function (Tabachnick and Fidell 1989). Because the native distribution of several species was interrupted by Shoshone Falls, we conducted separate canonical correlation analyses for data above and below the falls. All statistical analyses were performed with SAS statistical software (SAS Institute, Inc. 2009).

Within the study area, 4 species of sculpin occur, one of which (Wood River sculpin) is endemic only to the Big Wood River drainage. Fish-habitat relationships have already been developed for this species (Meyer et al. 2008) based on data collected as part of this study; therefore, we did not include this species in our analyses. Although the remaining 3 species of sculpin (mottled, Paiute, and shorthead) sometimes have disparate habitat preferences and distribution patterns (Peden et al. 1989, Quist et al. 2004b), in the Snake River basin of southern Idaho they appear to fill a similar habitat niche across the landscape, 
TABLE 2. Number of reaches surveyed and percentage of reaches in which native nongame fish species were collected known or probable native range for each species. Reaches unoccupied by a species are left blank to improve visualiza-

\begin{tabular}{|c|c|c|c|c|c|c|c|c|c|c|}
\hline & 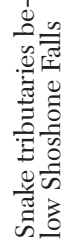 & 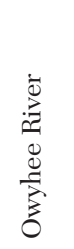 & 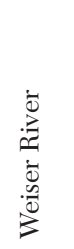 & 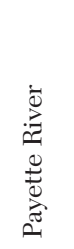 & 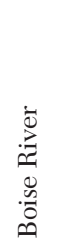 & 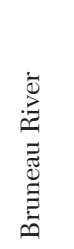 & 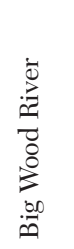 & 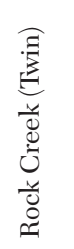 & 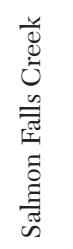 & 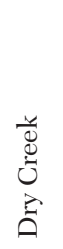 \\
\hline Number of reaches surveyed & 156 & 208 & 61 & 115 & 105 & 91 & 90 & 19 & 67 & 7 \\
\hline $\begin{array}{l}\text { Percentage of dry or nearly } \\
\text { dry reaches }\end{array}$ & 41.0 & 63.9 & 19.7 & 11.3 & 11.4 & 42.9 & 54.4 & 57.9 & 47.8 & 57.1 \\
\hline $\begin{array}{l}\text { Percentage of reaches with } \\
\text { fish (trout included) }\end{array}$ & 50.0 & 33.7 & 65.6 & 62.6 & 76.2 & 54.9 & 32.2 & 42.1 & 47.8 & 42.9 \\
\hline $\begin{array}{l}\text { Percentage of reaches with } \\
\text { nongame species }\end{array}$ & 32.7 & 22.1 & 29.5 & 16.5 & 44.8 & 36.3 & 27.8 & 21.1 & 40.3 & 14.3 \\
\hline $\begin{array}{l}\text { Percentage of reaches with } \\
\text { trout }\end{array}$ & 38.5 & 21.6 & 57.4 & 55.7 & 69.5 & 46.2 & 23.3 & 36.8 & 34.3 & 42.9 \\
\hline \multicolumn{11}{|l|}{ Percentage of reaches with ${ }^{c}$} \\
\hline Bridgelip sucker & 29.3 & 22.7 & 6.1 & 4.9 & 6.5 & 46.2 & 14.6 & 12.5 & 45.7 & \\
\hline Largescale sucker & & 5.3 & & 2.9 & & 1.9 & & & 2.9 & \\
\hline Mountain sucker & & 2.7 & & & & 1.9 & & & 5.7 & \\
\hline \multicolumn{11}{|l|}{ Utah sucker } \\
\hline Chiselmouth & 3.3 & 2.7 & & & 2.2 & 7.7 & & & 8.6 & \\
\hline Leopard dace & & & & & & & & 12.5 & & \\
\hline Longnose dace & 7.6 & 4.0 & 10.2 & 2.9 & 3.2 & 30.8 & 7.3 & 12.5 & 2.9 & \\
\hline Speckled dace & 46.7 & 54.7 & 12.2 & 11.8 & 2.2 & 48.1 & 14.6 & 50.0 & 65.7 & \\
\hline Redside dace & 21.7 & 30.7 & 8.2 & 5.9 & 6.5 & 51.9 & 7.3 & 12.5 & 48.6 & \\
\hline $\begin{array}{l}\text { Northern leatherside chub } \\
\text { Utah chub }\end{array}$ & & & & & & & & & $6.3^{\mathrm{a}}$ & \\
\hline Peamouth & & & & & & 1.1 & & & & \\
\hline Northern pikeminnow & 4.3 & 13.3 & 2.0 & 3.9 & 4.3 & 11.5 & & & 8.6 & \\
\hline Mottled sculpin & & 4.0 & 10.2 & 8.8 & 5.4 & 3.8 & & 12.5 & & 33.3 \\
\hline Paiute sculpin & & 13.3 & & & & & & & 48.6 & \\
\hline Shorthead sculpin & & 1.3 & 20.4 & 3.9 & 44.1 & 5.8 & & & & \\
\hline Wood River sculpin & & & & & & & 48.8 & & & \\
\hline
\end{tabular}

with allopatric-sympatric distribution patterns that appear somewhat indiscriminate within and among drainages. Thus, although we modeled each species separately, we also combined all sculpin species into one metric to assess whether this combination better described the distribution and abundance of sculpin in the study area, compared to what was ascertained for individual species.

\section{RESUlTS}

A total of 1738 reaches were surveyed in small streams in the Snake River basin above Hells Canyon Dam. Stream characteristics varied widely at the study reaches we sampled (Table 1), ranging from 696 to $2964 \mathrm{~m}$ in elevation, $0.1 \%$ to $32.5 \%$ in gradient, and 4 to
$1585 \mu \mathrm{S} \cdot \mathrm{cm}^{-1}$ in specific conductivity. Of the reaches surveyed, $30 \%$ were in first-order streams, $39 \%$ were second-order, $22 \%$ were third-order, $7 \%$ were fourth-order, and $<3 \%$ were fifth- and sixth-order.

Of the 1738 reaches surveyed, $34 \%$ were dry or nearly dry (i.e., contained too little water to support any fish species; Table 2). An additional $21 \%$ did not contain any fish, even though flowing water was present during sampling. At least one species of nongame fish was captured at $30 \%$ of the stream reaches surveyed. All 18 native nongame fish species still present in the study area were captured during our surveys.

The most widely distributed species was speckled dace (occupying $21 \%$ of surveyed reaches where they were potentially native, 
with backpack electrofishers in small streams in the Snake River basin of southern Idaho. Shaded gray areas indicate the tion of the data.

\begin{tabular}{|c|c|c|c|c|c|c|c|c|c|c|c|c|c|}
\hline 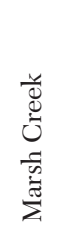 & 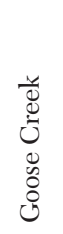 & 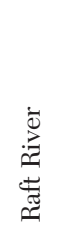 & 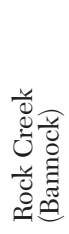 & 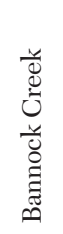 & 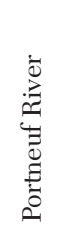 & 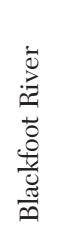 & 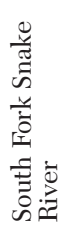 & 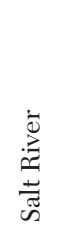 & 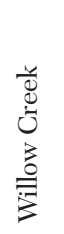 & 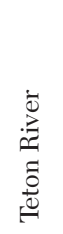 & 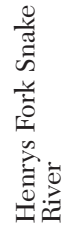 & 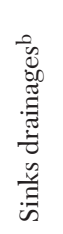 & 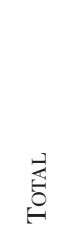 \\
\hline 10 & 81 & 92 & 16 & 6 & 82 & 76 & 80 & 64 & 58 & 89 & 87 & 78 & 1738 \\
\hline 20.0 & 37.0 & 31.5 & 87.5 & 33.3 & 12.2 & 18.4 & 33.8 & 9.4 & 39.7 & 27.0 & 18.4 & 25.6 & 33.7 \\
\hline 80.0 & 51.9 & 58.7 & 6.3 & 50.0 & 63.4 & 75.0 & 60.0 & 78.1 & 51.7 & 60.7 & 62.1 & 56.4 & 55.2 \\
\hline 30.0 & 27.2 & 27.2 & 6.3 & 33.3 & 36.6 & 43.4 & 28.8 & 51.6 & 43.1 & 18.0 & 33.3 & 15.4 & 30.2 \\
\hline \multirow[t]{11}{*}{80.0} & 45.7 & 58.7 & 0.0 & 50.0 & 58.5 & 56.6 & 57.5 & 75.0 & 39.7 & 60.7 & 58.6 & 55.1 & 47.8 \\
\hline & 13.7 & & & & & & 3.8 & 1.7 & & & 2.8 & & 2.0 \\
\hline & 3.9 & 6.3 & & & 8.3 & 16.1 & 3.8 & 12.1 & 20.0 & & 2.8 & & 4.1 \\
\hline & 3.9 & 1.6 & & & 2.8 & 3.2 & & 3.4 & 17.1 & & & 1.7 & 2.6 \\
\hline & & & & & & & & & & & & & $\begin{array}{l}2.8 \\
0.2\end{array}$ \\
\hline & 13.7 & 9.5 & & & & 4.8 & & 19.0 & 8.6 & 7.7 & 5.6 & & 7.0 \\
\hline & 31.4 & 9.5 & & & 5.6 & 27.4 & 7.5 & 19.0 & 25.7 & 9.2 & 14.1 & 1.7 & 21.4 \\
\hline & 17.6 & 11.1 & & & 1.4 & 6.5 & 1.9 & 10.3 & 31.4 & 1.5 & 9.9 & 1.7 & 13.5 \\
\hline & 11.8 & & & & & & & 1.7 & & & & & 1.2 \\
\hline & & 3.9 & 1.6 & & & 1.4 & 11.3 & & & & & & 1.8 \\
\hline & & & & & & & & & & & & & $\begin{array}{l}0.2 \\
6.3\end{array}$ \\
\hline \multirow[t]{3}{*}{37.5} & 29.4 & 36.5 & & & 11.1 & 17.7 & 9.4 & 22.4 & 42.9 & 7.7 & 12.7 & & 12.0 \\
\hline & 11.8 & 4.8 & 50.0 & 50.0 & 31.9 & 22.6 & 30.2 & 58.6 & 22.9 & 23.1 & 19.7 & & 15.5 \\
\hline & & & & & & & & & & & & 19.0 & $\begin{array}{l}12.4 \\
48.8\end{array}$ \\
\hline
\end{tabular}

excluding dry and nearly dry reaches; Table 2), followed by bridgelip sucker (19\%), Paiute sculpin $(16 \%)$, redside shiner $(14 \%)$, shorthead sculpin (12\%), and mottled sculpin (12\%). Although Wood River sculpin occupied 49\% of the surveyed reaches within their native range, excluding dry and nearly dry reaches, they were native to only one river drainage. Species found in $\leq 1 \%$ of the reaches where they were potentially native included leopard dace and peamouth, whereas northern leatherside chub, largescale sucker, Utah chub, and bluehead sucker were found in $\leq 2 \%$ of the reaches where they were potentially native.

Common carp Cyprinus carpio and oriental weatherfish Misgurnus anguillicaudatus were the only nonnative nongame fish species encountered during our surveys. Common carp were captured at one location each in the Rock Creek (Twin Falls), Portneuf River, and Boise River drainages. Oriental weatherfish were caught at 2 locations in the Boise River drainage, including one reach that also contained common carp. These 2 species were categorized as 'sparse' at each location where they were captured, and they were too rare to include in our statistical analyses.

When present, redside shiners were most often categorized as abundant (59\% of the reaches they occupied; Table 3), as were speckled dace $(55 \%)$ and all species of sculpin (on average, $50 \%$ ). Commonly occurring species that were rarely categorized as abundant included bluehead sucker $(10 \%)$, mountain sucker (15\%), chiselmouth (21\%), and northern pikeminnow $(22 \%)$. 
TABLE 3. Percentage of study reaches (excluding dry and nearly dry reaches) in small streams in the Snake River basin of southern Idaho where 18 fish species were absent, sparse, common, and abundant. Calculations for a species included data only from the drainages in which it was native.

\begin{tabular}{|c|c|c|c|c|}
\hline Species & Absent & Sparse & Common & Abundant \\
\hline Bluehead sucker & 98.0 & 0.8 & 1.0 & 0.2 \\
\hline Bridgelip sucker & 80.8 & 4.0 & 5.5 & 9.7 \\
\hline Largescale sucker & 98.4 & 0.9 & 0.0 & 0.7 \\
\hline Mountain sucker & 95.9 & 1.7 & 1.8 & 0.5 \\
\hline Utah sucker & 97.4 & 0.3 & 1.6 & 0.7 \\
\hline Chiselmouth & 97.2 & 1.2 & 1.0 & 0.6 \\
\hline Leopard dace & 99.8 & 0.2 & 0.0 & 0.0 \\
\hline Longnose dace & 93.0 & 1.6 & 2.8 & 2.6 \\
\hline Speckled dace & 78.6 & 3.5 & 6.1 & 11.8 \\
\hline Redside shiner & 86.5 & 1.8 & 3.7 & 7.9 \\
\hline Northern leatherside chub & 98.8 & 1.2 & 0.0 & 0.0 \\
\hline Utah chub & 98.2 & 0.5 & 0.7 & 0.7 \\
\hline Peamouth & 99.8 & 0.2 & 0.0 & 0.0 \\
\hline Northern pikeminnow & 93.7 & 2.6 & 2.4 & 1.4 \\
\hline Mottled sculpin & 88.0 & 2.8 & 4.6 & 4.6 \\
\hline Paiute sculpin & 84.5 & 3.6 & 5.5 & 6.4 \\
\hline Shorthead sculpin & 87.6 & 1.8 & 4.3 & 6.4 \\
\hline Wood River sculpin & 51.2 & 4.9 & 9.8 & 34.1 \\
\hline
\end{tabular}

The canonical correlation model constructed for species occurring below Shoshone Falls yielded 12 canonical functions, which collectively produced a statistically significant model $\left(\right.$ Wilks' $\lambda=0.27, F_{144,4307}=4.91, P<0.0001$ ) that explained a combined $73 \%$ of the variance shared between the variable sets across all functions. However, dimension reduction analysis indicated that only the first 4 functions (with squared canonical correlations of 0.49 , $0.18,0.16$, and 0.11 ) explained a significant ( $\alpha$ $=0.05$ ) amount of shared variance between the variable sets. Moreover, only the first function contained variables with cross-loadings of 0.30 and greater, which were thereby considered interpretable. This function explained $49 \%$ of the shared variance between the variable sets and indicated that the relative abundance of several species, including redside shiner, speckled dace, bridgelip sucker, northern pikeminnow, and chiselmouth, were all positively related to an increase in stream order (i.e., farther from headwaters), stream width, mean depth, and conductivity (Table 4). These species were all negatively related to stream gradient, stream shading, and elevation.

For species occurring above Shoshone Falls, the canonical correlation model was strikingly similar, yielding 12 canonical functions which collectively produced a statistically significant model (Wilks' $\lambda=0.33, F_{132,4290}=4.91, P$ $<0.0001)$ that explained a combined $67 \%$ of the variance shared between the variable sets across all functions. Dimension reduction analysis indicated that the first 4 functions (with squared canonical correlations of $0.47,0.15$, 0.09 , and 0.09) explained a significant amount of shared variance between the variable sets, but, once again, only the first function contained variables with cross-loadings 0.30 and greater. This function explained $47 \%$ of the shared variance between the variable sets and indicated that the relative abundance of speckled dace, mottled sculpin, longnose dace, redside shiner, mountain sucker, and Paiute sculpin were all positively related to an increase in stream order, mean depth, and stream wetted width (Table 4). These species were all negatively related to stream gradient and elevation.

Similar relationships were observed with logistic regression analyses (Table 5), and results were largely consistent for families of fish. For example, bridgelip and mountain sucker presence was more likely in reaches with lower gradient and less shading. Mountain sucker were also more likely to occupy reaches with less cobble-boulder substrate, whereas bridgelip sucker were more likely to occupy higher-order, lower-elevation stream reaches. Cyprinids (i.e., longnose dace, speckled dace, redside shiner, and northern pikeminnow) were also more likely to occupy lower gradient, lower elevation, higher-order reaches. In addition, longnose dace were more likely where cobble-boulder substrate was more abundant, whereas speckled dace and 
TABLE 4. Canonical cross-loadings for the first canonical function relating abiotic and biotic stream conditions to the relative abundance of select nongame fish species in the Snake River basin of southern Idaho. Separate models were run for sections downstream and upstream from Shoshone Falls. Only variables with loadings 0.30 and greater (in bold) should be considered interpretable. Missing values indicate where the species was not native.

\begin{tabular}{lcc}
\hline & \multicolumn{2}{c}{ From Shoshone Falls } \\
\cline { 2 - 3 } Variable & Downstream & Upstream \\
\hline Stream habitat parameter & & \\
Stream order & $\mathbf{0 . 6 3}$ & $\mathbf{0 . 5 6}$ \\
Elevation & $-\mathbf{0 . 3 5}$ & $-\mathbf{0 . 3 0}$ \\
Gradient & $\mathbf{- 0 . 4 7}$ & $\mathbf{- 0 . 4 2}$ \\
Conductivity & $\mathbf{0 . 3 6}$ & 0.25 \\
Stream width & $\mathbf{0 . 3 9}$ & $\mathbf{0 . 4 4}$ \\
Average depth & $\mathbf{0 . 3 0}$ & $\mathbf{0 . 4 9}$ \\
Width: depth ratio & 0.12 & 0.01 \\
Percent gravel substrate & 0.10 & -0.17 \\
Percent cobble- & -0.20 & -0.06 \\
$\quad$ boulder substrate & & \\
Stream shading & $-\mathbf{0 . 3 8}$ & -0.21 \\
Unstable banks & 0.12 & 0.19 \\
Trout density & -0.22 & -0.10 \\
Species relative abundance & & \\
Bluehead sucker & - & 0.17 \\
Bridgelip sucker & $\mathbf{0 . 5 4}$ & - \\
Largescale sucker & 0.13 & - \\
Mountain sucker & 0.16 & $\mathbf{0 . 3 7}$ \\
Utah sucker & - & 0.29 \\
Chiselmouth & $\mathbf{0 . 3 1}$ & - \\
Longnose dace & 0.28 & $\mathbf{0 . 3 9}$ \\
Speckled dace & $\mathbf{0 . 5 6}$ & $\mathbf{0 . 4 2}$ \\
Redside shiner & $\mathbf{0 . 6 0}$ & $\mathbf{0 . 3 8}$ \\
Northern pikeminnow & $\mathbf{0 . 4 0}$ & - \\
Utah chub & - & 0.14 \\
Mottled sculpin & 0.07 & $\mathbf{0 . 3 9}$ \\
Paiute scuplin & 0.10 & $\mathbf{0 . 3 7}$ \\
Shorthead sculpin & -0.02 & 0.07 \\
Sculpin combined & 0.09 & $\mathbf{0 . 5 4}$ \\
\hline & & \\
& & \\
& &
\end{tabular}

redside shiner were more likely where trout density was lower.

There was less consistency in the logistic regression models, and the models were generally weaker for cottids. Paiute and shorthead sculpin were both positively associated with higher stream order and more cobble-boulder substrate. Paiute sculpin were also positively associated with higher elevation but were negatively associated with gradient, conductivity, and stream width. Mottled sculpin were positively associated with conductivity and negatively associated with stream gradient. When all cottid species were combined into a conglomerate 'occupancy' metric, sculpin species were positively associated with stream order, elevation, gradient, stream width, and cobbleboulder substrate, but negatively associated with conductivity. Across all species, individual logistic regression models on average explained 34\% of the variation (range 12\%-53\%) in the presence/absence of native nongame fish species (Table 5). Predictive power was high for nearly all models, with area under the ROC curve averaging 0.84 across all models and ranging from 0.73 to 0.92 (Table 5).

\section{DisCuSSION}

The results of our study suggest that the distribution and abundance of many native nongame fish species in the Snake River basin of southern Idaho were influenced by abiotic and biotic stream conditions across the landscape. In general, catostomids and cyprinids formed a composite fish assemblage associated with higher-order, lower-elevation, lower-gradient reaches where conductivity was higher and streams were wider and deeper. Previous studies have demonstrated that similar catostomid-cyprinid fish assemblages (of generally the same species) were associated with similar stream conditions in western Wyoming (Quist et al. 2004b), eastern Oregon (Torgersen et al. 2006), and southern British Columbia (Porter et al. 2000). Surprisingly, nearly the exact same abiotic and biotic stream conditions scored canonical cross-loadings of 0.30 or greater for models applied to river drainages above and below Shoshone Falls (Table 4), despite the fact that 6 of the 14 species included in the analyses occurred only above or only below the falls. The similarity between these studies, and between our models applied to drainages both above and below Shoshone Falls, highlights the consistency in the influence that some reach-scale abiotic and biotic stream conditions may have on the abundance of nongame fish species, regardless of species composition or the additional influence of larger, regional-scale environmental conditions such as climate or geology.

Stream order was the strongest loading factor for canonical correlations in models applied to drainages above and below Shoshone Falls, suggesting that the increase in catostomids-cyprinids was occurring along a longitudinal downstream gradient. Longitudinal changes in fish assemblage structure are generally thought to be due either to continual species additions to downstream reaches (Sheldon 1968) or to biotic zonation resulting from 


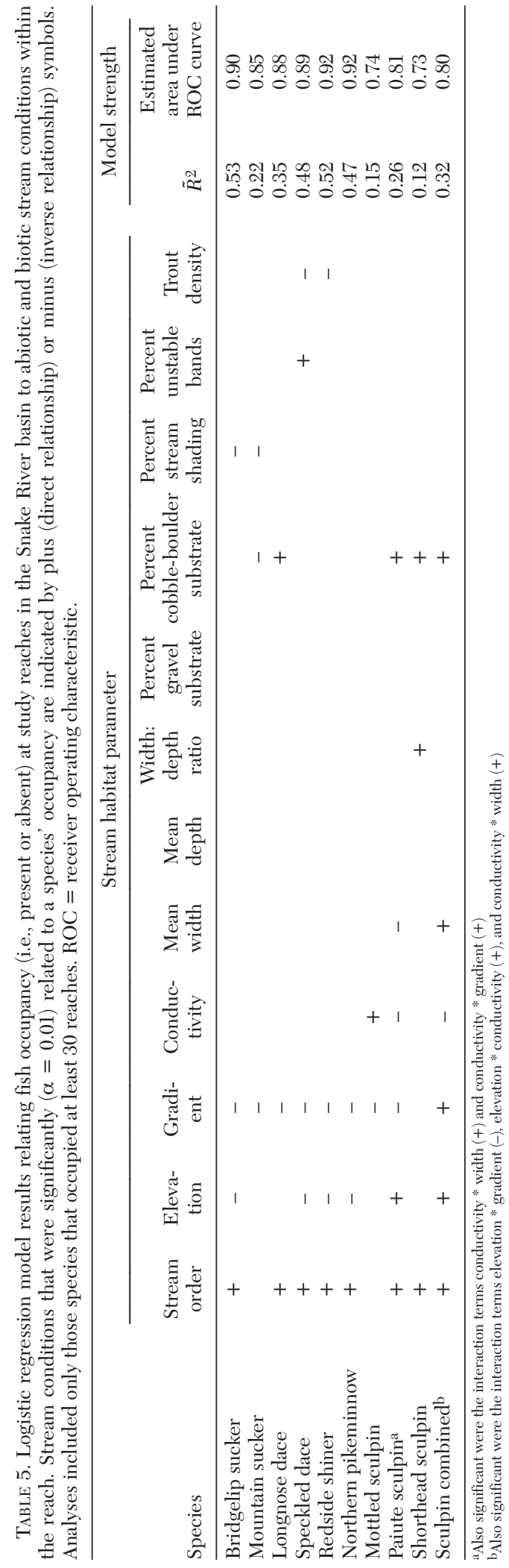

changes in geomorphology or thermal characteristics (Huet 1959). In our study, species such as sculpin, which are more closely associated with headwater streams, were still present at many of the lower elevation reaches, suggesting that biotic zonation perhaps had not yet materialized in our study for at least some species. However, as previously mentioned, we could not quantitatively sample streams larger than $15 \mathrm{~m}$ wetted width, thus zonation may have been unlikely to have occurred (or perhaps could not be detected) at the edge of our sampling framework.

Two cyprinids, speckled dace and redside shiner, were especially widespread and abundant. They were captured in all major river drainages (i.e., those greater than $1000 \mathrm{~km}^{2}$ ) and most of the smaller drainages (Table 2), and were more often categorized as abundant than were most other nongame species (Table 3 ). Both species are habitat generalists (Pearsons et al. 1992, Wydoski and Whitney 2003) and thus would be expected in a variety of stream conditions. Nevertheless, both showed an affinity for higher-order, lower-gradient, lower-elevation reaches. Longnose dace was the only species of the catostomid-cyprinid fish assemblage that was directly associated with cobble-boulder substrate. A positive association for longnose dace with cobble-boulder substrate has been demonstrated previously (Mullen and Burton 1995, Thompson et al. 2001) and probably results from longnose dace using substrates as shelter from the current (Culp 1989) or as a foraging mechanism to feed on macroinvertebrates on the surface of larger substrates (Thompson et al. 2001). None of the remaining cyprinids or catostomids were positively associated with cobbleboulder substrate, but 2 of the 3 sculpin species (and the conglomerate sculpin metric) were. Direct associations with rocky substrate have been repeatedly demonstrated for many stream-dwelling sculpin (e.g., Brown 1991, Hesthagen and Heggenes 2003, Meyer et al. 2008) and are likely the result of shelter, foraging, and spawning needs (Wydoski and Whitney 2003).

At least one of the 3 main Cottus species in the Snake River basin of southern Idaho (Paiute, mottled, and shorthead sculpin) was present in 317 reaches, and 2 species were sympatric in 49 reaches; no reaches contained all 3 species. The prevalence of Cottus species 
was not surprising since they are known to inhabit small mountain streams more so than most other nongame fish species in the Intermountain West. However, fish-habitat associations for sculpin were generally weaker and less consistent than for other nongame species in our study. Also, logistic regression model results differed, and the models were weaker for individual sculpin species compared to the conglomerate sculpin metric. As we originally hypothesized, perhaps these sculpin species fill a somewhat similar habitat niche across the Snake River basin in southern Idaho. If so, the weakness of individual sculpin models could stem in part from a somewhat haphazard distribution influenced more by geomorphic processes (Smith 1978) and stream capture events (Burridge et al. 2007) than by abiotic and biotic stream conditions. At smaller scales within the Snake River basin, habitat features may more prominently influence distribution patterns for sculpin populations. For instance, in one of the drainages included in our study (i.e., the Salt River), allopatric and sympatric distributions of Paiute and mottled sculpin were associated with elevation and thermal characteristics (Quist et al. 2004b). Alternatively, others have argued that, for sculpin populations, microhabitat and macrohabitat conditions are of little importance; rather, they are regulated most strongly by density-dependent processes such as competition for food and space (Petty and Grossman 1996, Grossman et al. 2006).

Surprisingly, nonnative nongame fish species were almost entirely absent from small streams in the Snake River basin in southern Idaho. While this is an encouraging finding, it should be noted that nonnative nongame species are prevalent in many larger rivers and lentic habitats in southern Idaho (IDFG 2007). In fact, 13 nonnative nongame fish species exist in the Snake River basin in southern Idaho, 9 of which were likely established from the release of aquarium pet fish, a problem that will probably worsen in the coming decades (Gertzen et al. 2008, Strecker et al. 2011). Of the remaining 4 species, only common carp and grass carp Ctenopharyngodon idella are widely distributed in southern Idaho. Idaho is largely devoid of commonly used bait fish such as fathead minnow Pimephales promelas, golden shiner Notemigonus crysoleucas, and red shiner Cyprinella lutrensis, in part because the use of live bait fish has been prohibited in Idaho since 1960, with other regulations dating back to 1941 that restricted most use of live bait for Idaho anglers. At present, exotic nongame fish have apparently not yet invaded small streams in southern Idaho, although climate change may increase the likelihood of successful invasions as warmer water temperatures alter the types of fish that can establish self-sustaining populations (Rahel and Olden 2008).

In our study, much of the variation in the occupancy and relative abundance of native nongame fish species in the Snake River basin was unexplained by our fish-habitat models (both canonical correlation and logistic regression), suggesting that nongame fish species population metrics were additionally influenced by other environmental factors that we did not measure. One such factor may be stream flow, which has been shown to influence nongame fish species assemblages (Poff and Allan 1995, Grossman et al. 1998), usually via effects on mortality and subsequent recruitment. Water temperature has also been shown to affect fish species assemblages (Porter et al. 2000, Quist et al. 2004b), although our metric of elevation might be considered a surrogate for water temperature (Bozek and $\mathrm{Hu}-$ bert 1992). Moreover, as our models consistently indicated, most of the species found in our study (except sculpin species) occurred at lower-elevation streams; thus, their occupancy and abundance were likely more closely associated with stream conditions in larger streams at lower elevations, rather than the small streams in our study. Unfortunately, quantitative sampling techniques for nongame fish species in larger streams are difficult to implement, and the abundance of many of these species (e.g., dace and shiners) can be overwhelming both in small streams and large rivers, due mainly to their schooling nature, making it difficult to quantitatively sample them in an unbiased manner. Fish-habitat relationships are often weak and not applicable to areas outside the study area where the relationships were developed (Fausch et al. 1988), in part because complex interactions between multiple habitat factors simultaneously affecting organisms are not all measured and accounted for in statistical models (Cade and Noon 2003), nor are they necessarily consistent spatially or temporally. 
Our probability of detecting a species at any given reach was not equal to one. Thus, at an unknown number of locations, we mistakenly concluded that a species was absent when in fact it was present at a reach. Not accounting for imperfect detection may have led to inaccurate conclusions regarding the magnitude of effect for each variable included in our models (MacKenzie 2005). Indeed, imperfect detection probability is an active area of research in applied ecology (e.g., MacKenzie et al. 2002, He and Gaston 2003, Royle et al. 2005). False species absences in our study probably occurred most often for the rarest species, and we did not attempt to identify stream conditions that influenced their occupancy. For the remaining species that were more abundant, errors still occurred at locations where their abundance was very low, but we do not believe that false absences in our data introduced substantial bias to our conclusions. Meyer and High (2011) concluded that, at measured capture efficiencies of $20 \%-60 \%$ for salmonids in the Snake River basin, if abundance was as low as only 2 fish in $100 \mathrm{~m}$ of stream, the likelihood of catching at least one of these fish with 3 depletion passes would be about $95 \%$. Although sculpin are more difficult to capture during electrofishing than salmonids (because sculpin are smaller and are less buoyant because they have no swim bladder), capture probabilities for Wood River sculpin were only about $35 \%$ lower than for salmonids (K. Meyer unpublished data).

Within the small streams of the Snake River basin above Hells Canyon Dam, we captured all 18 native nongame fish species still present in the study area. This was somewhat surprising because we surveyed $<1 \%$ of the stream kilometers included in our study area, and some species such as northern leatherside chub are extremely rare in the Snake River basin, while others are more closely associated with larger rivers (e.g., chiselmouth, northern pikeminnow) that we excluded from our study. While it is encouraging that all native nongame fish species were represented, most species were absent from a high percentage of study reaches, and, even when present, most species were rarely abundant. We believe that, for many species, this characteristic may be reflective of a stronger affinity for larger rivers rather than an actual decline in distribution or abundance.

Whether the distribution and abundance of native nongame fish species in southern Idaho has declined from historical levels cannot be ascertained from our results because (1) there is little previous work for comparison and (2) our exclusion of large rivers makes our current assessment incomplete. The ubiquity of studies across North America demonstrating a decline in the distribution and abundance of native nongame fish species (e.g., Warren et al. 2000, Haslouer et al. 2005, Hoagstrom et al. 2007, Moyle et al. 2011), as well as the declines in native game fish within our study area (e.g., Thurow et al. 1997), suggest that nongame fish species in southern Idaho have likely experienced some level of decline. However, perhaps more important is monitoring whether existing populations maintain their current distribution and abundance for the foreseeable future. Accordingly, future studies that fill the gaps in our data set or use our data as a baseline for direct comparison may more completely elucidate the current status of native nongame fish species in the Snake River basin of southern Idaho. This study underscores the need for management agencies to focus more effort on recording data for nongame fish species (rather than just the targeted game species of interest) during standard fish-sampling surveys, both in small, higher-elevation streams, where quantitative sampling is more easily conducted, and in larger downstream rivers, where quantitative sampling may be more difficult but many nongame species may be more likely to occur. An added benefit is that population metrics and distributions of nongame species may serve as better ecological indicators of change because the population dynamics of nongame species are less influenced by management actions.

\section{ACKNOWLEDGMENTS}

We thank the many field personnel who assisted in data collection, most notably John Cassinelli. Reviews by Tim Copeland, Chris Sullivan, Erin Larson, Chris Walser, and 2 anonymous reviewers greatly improved the manuscript. The states of Oregon, Nevada, Utah, and Wyoming generously permitted us access to streams within their jurisdiction.

\section{Literature Cited}

ALLAN, J.D. 1995. Stream ecology, structure and function of running water. Chapman and Hall, New York, NY. 
Angermeier, P.L., AND M.R. Winston. 1998. Local vs. regional influences on local diversity in stream fish communities of Virginia. Ecology 79:911-927.

Arend, K.K. 1999. Macrohabitat identification. Pages 7593 in M.B. Bain and N.J. Stevenson, editors, Aquatic habitat assessment: common methods. American Fisheries Society, Bethesda, MD. 216 pp.

BozeK, M.A., AND W.A. HuberT. 1992. Segregation of resident trout in streams as predicted by three habitat dimensions. Canadian Journal of Zoology 70: 886-890.

Brown, L.R. 1991. Differences in habitat choice and behavior among three species of sculpin (Cottus) in artificial stream channels. Copeia 1991:810-819.

Burns, A.D. 2007. Comparison of two electrofishing gears (backpack and parallel wires) and abundances of fishes of the upper Greenbrier River drainage. Master's thesis, West Virginia University, Morgantown, WV. $72 \mathrm{pp}$

Burridge, C.P., D. Craw, and J.M. Waters. 2007. An empirical test of freshwater vicariance via river capture. Molecular Ecology 16:1883-1895.

CADE, B.S., AND B.R. NoON. 2003. A gentle introduction to quantile regression for ecologists. Frontiers in Ecology and the Environment 1:412-420.

CuLP, J.M. 1989. Nocturnally constrained foraging of a lotic minnow (Rhinichthys cataractae). Canadian Journal of Zoology 67:2008-2012.

Fausch, K.D., C.L. Hawkes, and M.G. Parsons. 1988 Models that predict standing crop of stream fish from habitat variables: 1950-1985. General Technical Report PNW-GTR-213, USDA Forest Service, Pacific Northwest Research Station, Portland, OR.

Gertzen, E., O. Familiar, and B. Leung. 2008. Quantifying invasion pathways: fish introductions from the aquarium trade. Canadian Journal of Fisheries and Aquatic Sciences 65:1265-1273.

Grossman, G.D., R.E. Ratajczak, M. Crawford, and M.C. Freeman. 1998. Assemblage organization in stream fishes: effects of environmental variation and interspecific interactions. Ecological Monographs 68: 396-420.

Grossman, G.D., R.E. Ratajczak Jr., J.T. Petty, M.D. Hunter, J.T. Peterson, and G. GrenoullLet. 2006. Population dynamics of mottled sculpin (Pisces) in a variable environment: information theoretic approaches. Ecological Monographs 76:217-234.

Hair, J.F., JR., R.E. Anderson, R.L. Tatham, and W.C BLACK. 1998. Multivariate data analysis. 5th edition. Prentice Hall, Inc., Upper Saddle River, NJ.

Hanley, J.A., AND B.J. McNeIL. 1982. The meaning and use of the area under a receiver operating characteristic (ROC) curve. Radiology 143:29-36.

Haslouer, S.G., M.E. Eberle, D.R. Edds, K.B. Gido, C.S. Mammoliti, J.R. Triplett, and J.T. Collins. 2005. Current status of native fish species in Kansas. Transactions of the Kansas Academy of Science 108: 32-46.

He, F., and K.J. Gaston. 2003. Occupancy, spatial variance, and the abundance of species. American Naturalist 162:332-342.

Hesthagen, T., and J. Heggenes. 2003. Competitive habitat displacement of brown trout by Siberian sculpin: the role of size and density. Journal of Fish Biology 62:222-236.

High, B., K.A. Meyer, D.J. Schill, and E.R.J. Mamer. 2008. Distribution, abundance, and population trends of bull trout in Idaho. North American Journal of Fisheries Management 28:1687-1701.

Hoagstrom, C.W., S.S. Wall, J.G. Kral, B.G. BlackWELL, AND C.R. BERRY JR. 2007. Zoogeographic patterns and faunal changes of South Dakota fishes. Western North American Naturalist 67:161-184.

Hubbs, C.L., AND R.R. Miller. 1948. The zoological evidence: correlation between fish distribution and hydrographic history in the desert basins of western United States. Pages 17-166 in The Great Basin, with emphasis on glacial and postglacial times. Bulletin of the University of Utah, Biological Series 10, no. 38 .

Huet, M. 1959. Profiles and biology of western European streams as related to fish management. Transactions of the American Fisheries Society 88:155-163.

Hughes, R.M., P.R. Kaufmann, A.T. Herlihy, T.M. KinCAID, L. REYNolds, AND D.P. LARSEN. 1998. A process for developing and evaluating indices of fish assemblage integrity. Canadian Journal of Fisheries and Aquatic Sciences 55:1618-1631.

Hughes, R.M., L.W. Wang, and P.W. Seelbach. 2006. Landscape influences on stream habitats and biological assemblages. American Fisheries Society Symposium 48, American Fisheries Society, Bethesda, MD. 697 pp.

[IDFG] Idaho Department of Fish and Game. 2007. Fisheries Management Plan 2007-2012. Boise, ID.

JoHnson, J.B. 2002. Evolution after the flood: phylogeography of the desert fish Utah chub. Evolution 56: 948-960.

Lee, D.S., C.R. Gilber, C.H. Hocutt, R.E. Jenkins, D.E. McAllister, and J.R. Stauffer. 1980. Atlas of North American freshwater fishes. North Carolina Museum of Natural History, Raleigh, NC.

MacKenzie, D.I. 2005. What are the issues with presence-absence data for wildlife managers? Journal of Wildlife Management 69:849-860.

MacKenzie, D.I., J.D. Nichols, G.B. Lachman, S. Droege, J.A. Royle, and C.A. Langtimm. 2002. Estimating site occupancy rates when detection probabilities are less than one. Ecology 83: $2248-2255$.

Mebane, C.A., T.R. Maret, and R.M. Hughes. 2003. An index of biological integrity (IBI) for Pacific Northwest rivers. Transactions of the American Fisheries Society 132:239-261.

Menard, S. 1995. Applied logistic regression analysis. Sage Publications, Thousand Oaks, CA.

Meyer, K.A., F.S. Elle, and J.A. Lamansky. 2009. Environmental factors related to the distribution, abundance, and life history characteristics of mountain whitefish in Idaho. North American Journal of Fisheries Management 29:753-767.

MeYer, K.A., AND B. High. 2011. Accuracy of removal electrofishing estimates of trout abundance in Rocky Mountain streams. North American Journal of Fisheries Management 31:923-933.

Meyer, K.A., D.J. Schill, M.R. Campbell, and C.C. KOZFKAY. 2008. Distribution, abundance, and genetic population structure of Wood River sculpin, Cottus leiopomus. Western North American Naturalist 68: 508-520.

Meyer, K.A., D.J. Schill, J.A. Lamansky, M.R. CampBELL, AND C.C. KOZFKaY. 2006. Status of Yellowstone cutthroat trout in Idaho. Transactions of the American Fisheries Society 135:1329-1347. 
Moyle, P.B., J.V.E. Katz, and R.M. Quiñones. 2011. Rapid decline of California's native inland fishes: a status assessment. Biological Conservation 144: 2414-2423.

Mullen, D.M., And T.M. Burton. 1995. Size-related habitat use of longnose dace (Rhinichthys cataractae). American Midland Naturalist 133:177-183.

NageLKerke, N.J.D. 1991. A note on a general definition of the coefficient of determination. Biometrika 78: $691-692$

Pearsons, T.N., H.W. Li, AND G.A. Lamberti. 1992. Influence of habitat complexity on resistance and resilience of stream fish assemblages to flooding. Transactions of the American Fisheries Society 121: 427-436.

Peden, A.E., G.W. Hughes, and W.E. Roberts. 1989. Morphologically distinct populations of the shorthead sculpin, Cottus confusus, and mottled sculpin, Cottus bairdi, (Pisces, Cottidae), near the western border of Canada and the United States. Canadian Journal of Zoology 67:2711-2720.

Petty, J.T., and G.D. Grossman. 1996. Patch selection by mottled sculpin (Pisces: Cottidae) in a southern Appalachian stream. Freshwater Biology 35:261-276.

PofF, N.L., AND J.D. ALLAN. 1995. Functional organization of stream fish assemblages in relation to hydrological variability. Ecology 76:606-627.

Porter, M.S., J. Rosenfeld, and E.A. Parkinson. 2000. Predictive models of fish species distribution in the Blackwater drainage, British Columbia. North American Journal of Fisheries Management 20:349-359.

Quist, M.C., W.A. HuberT, And D.J. IsaAk. 2004a. Fish assemblage structure and relations with environmental conditions in a Rocky Mountain watershed. Canadian Journal of Zoology 82:1554-1565.

Quist, M.C., W.A. HuberT, AND D.J. IsaAK. 2004b. Factors affecting allopatric and sympatric occurrence of two sculpin species across a Rocky Mountain watershed. Copeia 2004(3):618-624.

Quist, M.C., W.A. Hubert, and F.J. Rahel. 2004c. Relations among habitat characteristics, exotic species, and turbid-cyprinids in the Missouri River drainage of Wyoming. Transactions of the American Fisheries Society 133:727-742.

Rahel, FJ., and J.D. Olden. 2008. Assessing the effects of climate change on aquatic invasive species. Conservation Biology 22:521-533.

Rashleigh, B., R. Parmar, J.M. Johnston, and M.C. BARBER. 2005. Predictive habitat models for the occurrence of stream fishes in the Mid-Atlantic Highlands. North American Journal of Fisheries Management 25:1353-1366.

ReID, S.M., N.E. Jones, AND G. YunKer. 2008. Evaluation of single-pass electrofishing and rapid habitat assessment for monitoring redside dace. North American Journal of Fisheries Management 28:50-56.

Reynolds, L., A.T. Herlihy, P.R. Kaufmann, S.V. GreGORY, AND R.M. Hughes. 2003. Electrofishing effort requirements for assessing species richness and biotic integrity in western Oregon streams. North American Journal of Fisheries Management 23: $450-461$.
Royle, J.A., J.D. Nichols, And M. KéRy. 2005. Modeling occurrence and abundance of species when detection is imperfect. Oikos 353:353-359.

SAS Institute, Inc. 2009. SAS/STAT ${ }^{\circledR} 9.2$ user's guide. 2nd edition. SAS Institute, Inc., Cary, NC.

SchiLL, D.J. 2009. Population studies of desert redband trout. Doctoral dissertation, University of Idaho, Moscow, ID. $180 \mathrm{pp}$.

SCOTT, M.C., AND L.W. HaLl. 1997. Fish assemblages as indicators of environmental degradation in Maryland coastal plain streams. Transactions of the American Fisheries Society 126:349-360.

Scott, W.B., and E.J. Crossman. 1973. Freshwater fishes of Canada. Fisheries Research Board of Canada Bulletin 184.

Sheldon, A.L. 1968. Species diversity and longitudinal succession in stream fishes. Ecology 49:193-198.

Simpson, J.C., AND R.L. Wallace. 1982. Fishes of Idaho. University of Idaho Press, Moscow, ID. 238 pp.

SмiтH, G.R. 1978. Biogeography of Intermountain fishes. Great Basin Naturalist Memoirs 2:17-42.

STRAHLER, A.N. 1964. Quantitative geomorphology of drainage basins and channel networks. Section 4-2 in V.T. Chow, editor, Handbook of applied hydrology. McGraw-Hill, New York, NY.

Strecker, A.L., P.M. Campbell, and J.D. Olden. 2011. The aquarium trade as an invasion pathway in the Pacific Northwest. Fisheries 36:74-85.

TABaChNick, B.G., AND L.S. Fidell. 1989. Using multivariate statistics. 2nd edition. HarperCollins, New York, NY.

TER BraAK, C.J.F., AND P.F.M. VERdonschot. 1995. Canonical correspondence analysis and related multivariate methods in aquatic ecology. Aquatic Sciences 57: $255-289$.

Thompson, A.R., J.T. Petty, and G.D. Grossman. 2001. Multi-scale effects of resource patchiness on foraging behavior and habitat use by longnose dace, Rhinichthys cataractae. Freshwater Biology 46:145-160.

Thurow, R.F., D.C. Lee, and B.E. Rieman. 1997. Distribution and status of seven native salmonids in the interior Columbia River Basin and portions of the Klamath River and Great basins. North American Journal of Fisheries Management 17:1094-1110.

Torgersen, C.E., C.V. BaXter, H.W. Li, and B.A. MCInTOSH. 2006. Landscape influences on longitudinal patterns of river fishes: spatially continuous analysis of fish-habitat relationships. American Fisheries Society Symposium 48:473-492.

Warren, M.L., H.W. Robison, S.T. Ross, W.C. Starnes, B.M. Burr, S.J. Walsh, H.L. Bart JR., R.C. CashNer, D.A. Etnier, B.J. Freeman, et al. 2000. Diversity, distribution, and conservation status of the native freshwater fishes of the southern United States. Fisheries 25:7-31.

Wydoski, R.S., AND R.R. WHITNEY. 2003. Inland fishes of Washington. 2nd edition. University of Washington Press, Seattle, WA.

Received 18 May 2012 Accepted 16 November 2012 